\title{
The involvement of non-formal education in students' learning needs during the covid-19 epidemic
}

\author{
Paisal Manurung ${ }^{* 1}$, Karimaliana², Rahma Yunita Ansi ${ }^{1}$, Dian Anggraini Harahap ${ }^{1}$, Datulina Ginting1 ${ }^{1}$ \& Heni \\ Subagiharti ${ }^{1}$ \\ ${ }^{1}$ English Education Study Program, The Faculty of Teacher's Training and Education, Universitas Asahan, Kisaran, 21216, North Sumatera, Indonesia \\ 2Indonesia and Literature Education Study Program, The Faculty of Teacher's Training and Education, Universitas Asahan, Kisaran, 21216, North \\ Sumatera, Indonesia \\ paisalmanurung@yahoo.com \\ *Corresponding Author: paisalmanurung@yahoo.com | Phone Number: +6281396434328
}

\section{ARTICLE INFO}

Received: 26-05-2021

Received in revised: 24-06-2021

Accepted: 19-07-2021

Available online: $30-8-2021$

\section{KEYWORDS}

Non-formal education;

Epidemic; Covid-19;

Education;

\begin{abstract}
A B S T R A C T
All Formal education is oriented towards the continuity of one's education to carry out formal learning activities from the pre-school level to the university level. This article asks about the involvement of non-formal education to fulfil the learning needs of students during the Covid-19 epidemic as a form of companion, complement, support and requirement. This article uses a qualitative descriptive design that takes the ideas, sources and theories based on reference books, related journals and experiences as well as from sources those who are experienced in their fields. So this article, the author states that the involvement of non-formal education is divided into two points, namely: 1) Direct involvements: a) extracurricular involvement, b) technology system involvement of subjects matters, c) involvement of school activity companions, d) involvement of supporting of vision and mission of the school. 2) Indirect involvements: a) involvement of companion learning resource's needed, b) involvement of flexibility learning activities, c) involvement of potential trainers of students, d) involvement of prerequisites for admission to favourite study and e) involvement the lifelong education's changement.
\end{abstract}

\section{INTRODUCTION}

Non-formal education is also what is known as extramural education. Non-formal education and outside school education have the same pattern and structure Dugarova, Starostina, Namsarayev, Dagbaeva, \& Malanov (2016). This statement gives us the informations that there are meanings of teaching and learning which are two words that cannot be separated in the educational process itself, but in concept and theory. The teaching and learning process has different characteristics, models, methods and approaches. Haerullah (2020) said that differences in the teaching and learning process will affect the child's mindset, character, potential, and ability to solve problems and find solutions to accepted problems.

In the fact today in the new era of Covid-19 pandemic of formal school is lack of a pre-school educational facility for students to continue their education up according to Harris \& Wihak, (2018); (Werquin, n.d.) But, it was formal schools have not been able to provide satisfaction to students to develop the potential, competencies and skills they should have obtained informal education. While formal education at the senior high school level is more oriented towards learning and teaching, doing assignments, discussing assignment problems, and preparing for education to the university level according to Ivanova (2016); Storey \& Slavin (2020), however at the first school level, formal schools are more oriented towards preparing children to receive information from reading books, teacher lectures and doing assignments. And so it is in elementary level formal schools. Schools are more oriented towards preparing students to receive information from books, teacher lectures and assignments according to Kegiatan, Masyarakat, Rizka, \& Hardiansyah (2017). Based on the beside statement according to Küçüksüleymanoğlu (2018); Tajik, Farnaz Vahedi (2021) said that he consequence is that if it continues, it will become an obstacle to the potential, competence, and independence of students to be able to create, explore, renovate knowledge, experience as a source of learning and the skills they will develop from an 
early age will be hampered. Based on Kuntoro (2006); Ngozwana (2017); O'Connor (2012) said that another assumption is of course seeing that a person's ability and readiness to undergo dead-end education cannot be separated from what is called life skills. According to Rogers (2005); Silberman-Keller (2003); Skager et al., n.d.; Sudaryana (2018); Young \& Donovan (2020) give statements that the importand aspects of life skills are independence of students in gaining knowledge and learning experiences as a form of the learning process in formal schools implies cognitive, affective and psychomotor abilities, and not to the aspects of deepening the experience of science, technology, information, and mathematics. This is also an inseparable part of formal education so that nonformal education becomes a part that is supporting, complementary, companion and conditional according to Sulfasyah \& Arifin (2017); Sumalee (2018). In the conditions of the new era or new era norms, non-formal education may become a core part of the need for education aacording to Susanti (2014). Younus \& Akbar (2017) said that Non-formal education is outdoor education, it was although in theory and practice, nonformal education does not yet have a standard education management proces.

\section{LITERATURE REVIEW}

\section{Implementation of Non-Formal Education}

The implementation of non-formal education is education outside formal education activities carried out in the process of proficiency and expertise, and it was the process of proficiency and expertise suggests that non-formal education is capable and able to explore students and to seek the need for knowledge accordint to Ugwu, n.d.; Vovk, Sotska, Trynus, \& Muzyka (2019). This is of course in line with what was conveyed Rogers (2005) stated that nonformal education provides opportunities and challenges for students to face changes to their environment in applying the knowledge they have acquired as solutions to life problems. In other implementations, what was conveyed by accordig to Syaparuddin (2020); Tajik, Farnaz Vahedi (2021) that the value of implementing non-formal education includes 1) developing values and skills, 2) building collaboration skills, 3) supporting one another, 4) leadership. Young \& Donovan (2020); Yazcayir \& Gurgur (2021) sees that other implementations of non-formal education must involve the implementation of facilities and infrastructure, what will be taught, how to advocate, directly and indirectly, using a hidden curriculum covering community habits, the meaning and values of teachers and the meaning of students in non-formal education.

The implementation of non-formal education in Indonesia is based at this time to help complete the compulsory 9-year basic education program, being involved in the compulsory education program education services according to DeArmond, Chu, \& Gundapaneni (2021). It was the same conditions with Dugarova et al., (2016); Fragouli (2020); Haerullah (2020) the emergence of the equivalency education program in non-formal education, namely the Package A program equivalent to elementary school, Package B equivalent to junior high school, package $\mathrm{C}$ equivalent to SMA was more triggered by the need to complete the 9-year compulsory basic education program (Package A and Package B) in addition to providing access to higher education namely Package $\mathrm{C}$. RI Law No. 20 of 2003 concerning the National Education System Article 26 paragraph 1 states as follows: Nonformal education is provided for citizens who need educational services that function as substitutes, enhancers, and/or complement to formal educators to support lifelong education according to Kegiatan et al. (2017).

\section{Development of Quality of Non-Formal Education}

The development of the quality of non-formal education in the pandemic era is of course through various methods and strategies as a form of development and quality of nonformal education Karasel Ayda, Bastas, Altinay, Altinay, \& Dagli (2020). Based on the development of the quality of non-formal education, education is a conscious, planned effort to create an atmosphere of learning and the learning process so that students actively develop their potential to have religious-spiritual strength, self-control, personality, intelligence, noble character, and the necessary skills. thereof, society, nation and State said Susanti (2014); Sulfemi (2019); Suswandari, Siswandari, Sunardi, \& Gunarhadi (2020).

The education, noble, healthy, knowledgeable, competent, creative, independent, and being a democratic and national citizen function to develop capabilities and shape the character and civilization of the nation to develop the potential of students to become faithful and devoted people to God who is most responsible. (Law No. 20 of 2003 on the National Education System). In-Law No. 20 of 2003 concerning the National Education System article 13 paragraph 1 , it is stated that the implementation of the Indonesian national education system is subject to 3 steps, namely formal, non-formal, and informal education channels that can complement and enrich each other Terrazas-Marín (2018). Non-formal education is a path of education outside formal education that can be implemented in a structured and tiered manner said Suswandari et al.(2020); Syaparuddin (2020). In the other statetement that it is non-formal education includes life skills education, early childhood education, youth education, women's empowerment education, literacy education, skills education and job training, equality education, and other education aimed at developing the abilities of students. In-Law Number 20 of 2003 concerning 
the national education systematics according to Suswandari et al. (2020); Tajik, Farnaz Vahedi (2021); Sulfemi (2019). This target not only prioritizes those who have never attended school, dropped out of school, or those who have graduated from school and want to get a job, but non-formal education also serves all levels of society without exception including those who already have a high level of education or even a permanent job said Blagg, Blom, Gallagher, \& Rainer (2020); Dugarova et al.(2016).

\section{Characteristics of Non-Formal Education in Pandemic Era}

The characteristics of non-formal education are of course assumed to be an approach that can contribute to students in preparing for their needs for deepening the material and competencies they have according to Education (2021). Efforts to improve the effectiveness of non-formal education are not an easy task, like turning your hands, even though in its history non-formal education is older than formal education. Based on the characteristics of nonformal education by Fragouli (2020) : a. It is necessary to organize the right concept of non-formal education programs. b. It is necessary to plan a needs-based nonformal education program of real learning. c. Implementing and managing non-formal education diligently and sustainably with clearer management principles. According to Sarfo, Amankwah, Baafi-Frimpong, \& Asomani (2020); Seifu (2020); Willis, Lynch, Fradale, \& Yeigh (2019) determines one of the phenomenan in the pandemic condition is to use of technology system as source to learn and to study.

Ngozwana (2017) states that the characteristics of nonformal education are the complementary and cover to learn, to educate and to life together as the formal education orientation. It was said Erol \& Danyal (2020); Yanuarti (2018) it is a direct link to the approach of pedagogy as a form of teaching and learning. This is followed by providing several characteristics such as 1) Youth shift, 2) Forming groups, 3) Community Center, 4) Short education system, 5) Focusing on local culture. According to Hermanto, Rai, \& Fahmi (2021) judging from the target, non-formal education includes all levels of society, not limited to age, gender, socio-economic status and level of education.

\section{Learning and Teaching as Non-Formal Education}

Non-formal education is certainly not the same as what is called teaching and learning Haerullah (2020). However, on the one hand, what is called formal education is also considered non-formal education. It was of course, this has a strong basis that this is due to a shift in the function of education in society, even though formal education is still a source of learning centres in modern times. And both of these things occur due to a shift in politics, government policies, culture, and a shift in values in society. And therefore, non-formal education has also taken a place in society as a choice of continuing education, experience development, and learning opportunities through criticizing political life according to Harris \& Wihak (2018); . Non-formal education gives status to students in obtaining this education. This status has cut off the uniqueness and potential of students and parents in providing non-formal education in society, this greatly affects the moral, norm aspects and the cultures as the unity of the society in the other district Karasel Ayda et al. (2020). So it was that nonformal education in the community is unique and has a special function in its belief as a form of framework support in society. Based on what is stated in the points above, according to Kuntoro (2006); Lemberger \& McCormick (1976) learning and teaching non-formal education can also be said to be learning and teaching as alternative education. In the words, where the learning and teaching functions are complementary to formal education, and if the formal education system finds problems in education, alternative education offers it as alternative education. Consequently, it was that non-formal education is also adult education. So that adult education today needs to be considered as a medium and a forum for many people to continue to create, renovate, and think critically in achieving the expected goals.

\section{METHODS}

This study is more oriented towards the idea and development of ideas on the source of the problem or phenomenon that is seen in society at large, and is consistent and assimilated to the current situation Noor, Isa, \& Mazhar (2020); Suswandari et al. (2020). The approach used in this study article is qualitative design Erol \& Danyal (2020). In this design, the author uses books, reputable international journals and reputable accredited national journals, and discusses these issues with experts in their fields, and this is also related to the author's experience. There are some point of views, such as: Participant is to determine the real condition to involve the non-formal education. Participant: participants used purposive sampling to collection of the data otentics. The participants involve the lectures, teachers, and students form the different field. Research Design: In this research design, the reseacher uses some of the different sources to determine the information taken from the partipants' data. Semi structure interview was developed to determine the questions according to aim of the research. Data analysis: Data analysis gives the gap information which is occured in the real society of non-formal education aspect. This gab descripbed based on the participants information and semi structure interview and compared with some national and international journal. 


\section{RESULTS AND DISCUSSIONS}

In the conceptual framework and theory of the implementation of non-formal education in Indonesia, especially for people affected by the Covid 19 pandemic, formal education can be achieved with the existence of nonformal education that has been determined for its function and practice in society, including:

\section{Non-Formal Education's Technology System}

Non-formal education as a technology system for formal education can be said that non-formal education provides opportunities for students to get an education in skill levels and increase competences. But in fact, some formal school, technology is less used in learning activity as the sources of learning and teaching. So that. It is section non-formal education provides opportunities for participants, for those who are unable to complete formal education due to school fees, distant schools and other reasons. In this section nonformal education will be very helpful for those who do not have sufficient funds to obtain a formal education. Then another alternative is to enter students into non-formal education. In the other cases appear that there are many technology system used to apply in learning and teaching such as webinar, google class room, gamingfication, and microsoft team. this system will give the appotunity for the teacher to collaborate with the student learning's need.

\section{Non-Formal Education as flexibility}

Non-formal education as a flexibility can be interpreted that non-formal education becomes a flexible education for what students do not get at school. This non-formal education process can be interpreted as companion or guidance in learning, enrichment of material and deepening of material. In the mentoring process, of course, many things can be done to improve knowledge, experience and learning processes that are not limited to time and place. Flexible will be unique to the students to learn, to be, to do, and to life together in the different time, condition and situation.

\section{Non-Formal Education as Complementary}

Non-formal education is a term that formal education requires a complement to non-formal education. The meaning of complement is that students can get additional information from what they have learned in formal schools. Not all of the tasks or materials in school must be implemented in school, of course, these tasks or materials can be done by attending non-formal education. For example, when the teacher explains to students about mathematical formulas, or about graphs, with non-formal education students can develop formulas or strategies that can be obtained more. For example graphics, with the entry of participants in non-formal education, students can see forms and examples or other alternatives to ways, methods, strategies to make graphics that are easier and more innovative.

\section{Non-Formal Education as a Requirement}

Non-formal education as a condition can also help students to enter the higher education they want. Non-formal education is not only a material deepening and sharpening the competence of students but also has the opportunity to enter the tertiary education they want. It has been proven that many universities provide requirements for prospective new students to have the competency of what they can do. This is important considering the potential that prospective students have to study at this institution. For example, universities make it easy for prospective students to enter higher education, if they have memorized the Quran 15-30 Jus Surat Al-Quran, give a discount for tuition, if prospective students can have the required competencies, and there are also scholarships.

\section{CONCLUSIONS}

Non-formal education is also an alternative education or out-of-school education in flexibility. This non-formal education greatly contributes and benefits students due to the lack of information they receive from formal schools. This non-formal education is also very helpful for teachers and schools in meeting the competencies that the school applies in technology system as the real learning students' need. Then with the presence of non-formal education, during this pandemics, it will make a real contribution in the form of deepening the material and sharpening the competence of students in the form of functions and forgiveness when non-formal education is a substitute, complement, companion and sign to the next changement.

\section{Acknowledgement}

The author would like to thank to Universitas Asahan and all lectures from the Teaching and Education Faculty and student of post-graduate Universitas Negeri Padang that have contributed in the form of materials, ideas and input for the improvement of this article.

\section{Author's Contributions}

All authors discussed the results and contributed to from the start to final manuscript.

\section{Conflict of Interest}

The authors declare that they have no competing interests.

\section{REFERENCES}

Blagg, K., Blom, E., Gallagher, M., \& Rainer, M. (2020). Mapping Student Needs during COVID-19 An Assessment of Remote Learning Environments. Education Data and Policy Center, 27.

DeArmond, M., Chu, L., \& Gundapaneni, P. (2021). How Are School Districts Addressing Student Social-Emotional Needs 
during the Pandemic? Center on Reinventing Public Education, (February 2021).

Dugarova, D. T., Starostina, S. E., Namsarayev, S. D., Dagbaeva, N. Z., \& Malanov, I. A. (2016). Non-formal education as a factor in civilizational development of educational space subject in the cross-border region. International Journal of Environmental and Science Education, 11(18), 1109711117.

Education, U. (2021). Education And Covid-19 Education And Covid-19 Ensure Safe Return To Learning, Despite widespread school closures, USAID programs a variety of in-person and distance approaches . play key roles in COVID-19 response efforts across sectors ., (January), 1-6.

Erol, K., \& Danyal, T. (2020). Analysis of distance education activities conducted during COVID-19 pandemic. Educational Research and Reviews, 15(9), 536-543. https://doi.org/10.5897/err2020.4033

Fragouli, E. (2020). A critical discussion on issues of higher education: Curriculum internationalization, challenges, and opportunities. International Journal of Education and Learning, 2(2), 67-75. https://doi.org/10.31763/ijele.v2i2.110

Haerullah, H. (2020). Dimensi Perkembangan Pendidikan Formal Dan Non Formal. Jurnal Edukasi Nonformal, 190-207.

Harris, J., \& Wihak, C. (2018). The recognition of non-formal education in higher education: Where are we now, and are we learning from experience? Journal of Distance Education, 33(1), 1-20.

Hermanto, Rai, N. G. M., \& Fahmi, A. (2021). Students' opinions about studying from home during the COVID-19 pandemic in Indonesia. Cypriot Journal of Educational Sciences, 16(2), 499-510. https://doi.org/10.18844/CJES.V16I2.5627

Ivanova, I. V. (2016). Non-formal Education: Investing in Human Capital. Russian Education and Society, 58(11), 718-731. https://doi.org/10.1080/10609393.2017.1342195

Karasel Ayda, N., Bastas, M., Altinay, F., Altinay, Z., \& Dagli, G. (2020). Distance Education for Students with Special Needs in Primary Schools in the Period of CoVid-19 Epidemic. Propósitos y Representaciones, 8(3). https://doi.org/10.20511/pyr2020.v8n3.587

Kegiatan, P., Masyarakat, B., Rizka, M. A., \& Hardiansyah, R. (2017). Analisis Strategi Fund Raising dalam Penyelenggaraan Program Pendidikan Nonformal pada Pusat Kegiatan Belajar Masyarakat Ceria. Journal of Nonformal Education, 3(2), 158-163. https://doi.org/10.24914/jne.v3i2.10951

Küçüksüleymanoğlu, R. (2018). Integration of Syrian Refugees and Turkish Students by Non Formal Education Activities. International Journal of Evaluation and Research in Education (IJERE), 7(3), 244.

https://doi.org/10.11591/ijere.v7i3.14118

Kuntoro, S. A. (2006). Pendidikan Nonformal (Pnf) Bagi Pengembangan Sosial. Jurnal Ilmiah VISI PTK-PNF, 1(2), 14-18. Diambil dari https://core.ac.uk/download/pdf/295555318.pdf

Lemberger, M. A., \& McCormick, W. C. (1976). Continuing education as a life-long process. American journal of pharmaceutical education vol.40.
Ngozwana, N. (2017). Rehabilitating Ex-Offenders Through NonFormal Education in Lesotho. IAFOR Journal of Education, 5(1), 111-121. https://doi.org/10.22492/ije.5.1.06

Noor, S., Isa, F. M., \& Mazhar, F. F. (2020). Online Teaching Practices During the COVID-19 Pandemic. Educational Process: International Journal, 9(3), 169-184. https://doi.org/10.22521/edupij.2020.93.4

O'Connor, U. (2012). Schools together: Enhancing the citizenship curriculum through a non-formal education programme. Journal of Peace Education, 9(1), 31-48. https://doi.org/10.1080/17400201.2012.657357

Rogers, A. (2005). Non-Formal Education - Flexible Schooling or Participatory Education? / Springer. Diambil dari http://www.springer.com/gp/book/9780387246369

Sarfo, F. K., Amankwah, F., Baafi-Frimpong, S., \& Asomani, J. (2020). Concerns of Teachers about the Implementation of Information and Communication Technology Curriculum in Basic Education in Ghana. Contemporary Educational Technology, 8(2), 103-118. https://doi.org/10.30935/cedtech/6190

Seifu, K. (2020). Determinants of information and communication technology integration in teaching-learning process at Aksum University. Cogent Education, 7(1). https://doi.org/10.1080/2331186X.2020.1824577

Silberman-Keller, D. (2003). Toward the Characterization of NonFormal Pedagogy. American Educational Research Association.

Skager, R., Dave, R. H., Cropley, A. J., Skager, R., Education, L., Cropley, A. J., ... Education, L. (n.d.). Curriculum Evaluation for Lifelong Education Preparing Teachers for Lifelong Education Areas Of Learning Basic To (Vol. 1).

Storey, N., \& Slavin, R. E. (2020). The US Educational Response to the COVID-19 Pandemic. Best Evidence of Chinese Education, 5(2), 617-633. https://doi.org/10.15354/bece.20.or027

Sudaryana, B. (2018). The Development of Smart House Model in Garut; The Advancement of Non-Formal Education Program. Asian Journal of Contemporary Education, 2(2), 84-89. https://doi.org/10.18488/journal.137.2018.22.84.89

Sulfasyah, S., \& Arifin, J. (2017). Implikasi Pendidikan Nonformal Pada Remaja. Equilibrium: Jurnal Pendidikan, 4(2), 1-8. https://doi.org/10.26618/equilibrium.v4i2.506

Sulfemi, W. B. (2019). Modul Manajemen Pendidikan Non Formal. https://doi.org/10.31227/osf.io/p9bez

Sumalee, S. (2018). Building the capability of non-formal education teachers to develop a learning society for promoting lifelong education in Thailand. International Journal of Educational Administration and Policy Studies, 10(2), 10-16. https://doi.org/10.5897/ijeaps2017.0536

Susanti, S. (2014). Meningkatkan Efektivitas Pendidikan Nonformal Dalam Pengembangan Kualitas Sumber Daya Manusia. jurnal Handayani, 1(2), 9-19.

Suswandari, M., Siswandari, Sunardi, \& Gunarhadi. (2020). Social skills for primary school students: Needs analysis to implement the scientific approach based curriculum. Journal of Social Studies Education Research, 11(1), 153162. 
Syaparuddin, S. (2020). Peranan Pendidikan Nonformal Dan Sarana Pendidikan Moral. Jurnal Edukasi Nonformal, 1(1), 173-186. https://ummaspul.ejournal.id/JENFOL/article/view/317

Tajik, Farnaz Vahedi, M. (2021). Quarantine and education: an assessment of Iranian formal education during the COVID19 outbreak and school closures Farnaz Tajik Ministry of Education, Iran. International Journal of Education and Development using Information and Communication Technology (IJEDICT), 17(February), 159-175.

Terrazas-Marín, R. A. (2018). Developing non-formal education competences as a complement of formal education for STEM lecturers. Journal of Education for Teaching, 44(1), 118-123. https://doi.org/10.1080/02607476.2018.1422613

Ugwu, C. U. (n.d.). Evolution and Revolutions of Adult Learning : Capacity Building in Adult and Non-Formal Education in Nigeria, 203-211.

Vovk, M. P., Sotska, H. I., Trynus, O. V., \& Muzyka, O. J. (2019). Assessment of instructors' technology competency to be used in the settings of formal and non-formal education. International Journal of Higher Education, 8(5), 29-44. https://doi.org/10.5430/ijhe.v8n5p29
Werquin, P. (n.d.). Recognising Non-Formal and Informal Learning.

Willis, R. L., Lynch, D., Fradale, P., \& Yeigh, T. (2019). Influences on purposeful implementation of ICT into the classroom: An exploratory study of K-12 teachers. Education and Information Technologies, 24(1), 63-77. https://doi.org/10.1007/s10639-018-9760-0

Yanuarti, E. (2018). Pemikiran Pendidikan Ki. Hajar Dewantara Dan Relevansinya Dengan Kurikulum 13. Jurnal Penelitian, 11(2), 237-266. https://doi.org/10.21043/jupe.v11i2.3489

Yazcayir, G., \& Gurgur, H. (2021). Students with Special Needs in Digital Classrooms during the COVID-19 Pandemic in Turkey. Pedagogical Research, 6(1), em0088. https://doi.org/10.29333/pr/9356

Young, J., \& Donovan, W. (2020). Challenges for students, families, and teachers, (June).

Younus, F., \& Akbar, R. A. (2017). Comparison of evaluation methods of teaching practice of formal and non-formal teacher education institutions of Punjab. Bulletin of Education and Research, 39(1), 159-173. http://pu.edu.pk/images/journal/ier/PDFFILES/12_39_1_17.pdf. 